\title{
Evidence of a resource trade-off between growth and chemical defenses among Caribbean coral reef sponges
}

\author{
Wai Leong, Joseph R. Pawlik* \\ Department of Biology and Marine Biology, Center for Marine Science, University of North Carolina Wilmington, \\ 5600 Marvin K Moss Lane, Wilmington, North Carolina 28409, USA
}

\begin{abstract}
Like all organisms, sponges allocate resources to life functions such as growth and reproduction. Additionally, some sponges are defended by secondary metabolites that deter potential predators. Assuming resources are limiting, species that produce defensive metabolites should allocate fewer resources to growth and reproduction. To test the hypothesis that there is a trade-off between chemical defense and growth, predator exclusion experiments were conducted to compare the growth rates of 7 common Caribbean sponge species with similar branching morphologies: chemically undefended species Callyspongia armigera, Iotrochota birotulata and Niphates erecta, and defended species Amphimedon compressa, Aplysina cauliformis, Aplysina fulva and Ptilocaulis walpersi. Thirty field experiments lasting 124 to $195 \mathrm{~d}$ were performed over a $9 \mathrm{yr}$ period on a total of 1158 sponges. A 3-factor ANOVA was used to compare the effects of chemical defense (undefended/ defended), treatment (uncaged/caged) and season (summer/winter). Despite the fact that different sponge species could be allocating resources differently to reproduction, thereby potentially obscuring the interaction between growth and chemical defense, growth in cages was significantly greater for undefended than defended sponges (110.4 versus $65.8 \%$ growth $\mathrm{yr}^{-1}$ ). While the growth of chemically defended sponges inside and outside of cages was not different, growth of undefended sponges inside cages was significantly greater than outside cages, confirming that palatable sponge species were grazed by sponge-eating fishes. Growth during winter months was significantly less for both undefended and defended sponges compared to growth during summer months, but again, growth was greater for undefended sponges than for defended sponges. Differences in growth rates demonstrate that sponge species have evolved alternative allocation patterns to cope with resource constraints, as well as predation, and provide evidence that there is a metabolic cost associated with chemical defenses.
\end{abstract}

KEY WORDS: Predation $\cdot$ Growth $\cdot$ Optimal defense $\cdot$ Tolerance $\cdot$ Coral reef

\section{INTRODUCTION}

Terrestrial plants produce many chemical and physical defenses against herbivory (Berenbaum \& Zangerl 2008). Yet under similar levels of herbivory, defended plants commonly co-occur with undefended plants. Several hypotheses have been put forth to explain phenotypic, genetic and geographical variation in plant defenses (Stamp 2003, Agrawal 2007). According to the resource availability hypothesis, plants allocate resources from a finite pool, resulting in trade-offs between defense, growth and reproduction (Coley et al. 1985, Bazzaz et al. 1987, Bazzaz \& Grace 1997). A plant can either resist predation by producing deterrent compounds or tolerate predation by allocating resources to growth and reproduction, and many examples of growth and defense trade-offs have been described (e.g. Herms \& Mattson 1992, Fine et al. 2006).

Like terrestrial plants, Caribbean coral reef sponges are also subject to grazing (Randall \& Hartman 1968, 
Dunlap \& Pawlik 1996, Pawlik 1998, León \& Bjorndal 2002, Loh \& Pawlik 2009). Observations of fish feeding on reef sponges have demonstrated that spongivorous fishes selectively feed on sponges (Dunlap \& Pawlik 1996, Pawlik 1997, Loh \& Pawlik 2009). Organic extracts of the tissues of 73 Caribbean sponge species exhibited a wide range of feeding deterrent activities in experiments with a generalist predator, the blue-head wrasse Thalassoma bifasciatum (Pawlik et al. 1995), and these preferences mirrored those of the spongivorous fishes (Dunlap \& Pawlik 1996, Pawlik 1997, 1998). Based on laboratory and field feeding experiments as well as predation exclusion experiments, Pawlik $(1997,1998)$ grouped sponges into 3 categories: 'preferred' sponge species are rapidly grazed down and only survive in cryptic refugia, while 'undefended' and 'defended' species both co-exist on the reef. Some of the secondary metabolites responsible for deterrent activity in defended sponges have been isolated and identified (e.g. Albrizio et al. 1995, Puyana et al. 2003, Nuñez et al. 2008). Assuming these complex compounds require metabolic energy to synthesize, store and deploy, a trade-off between chemical defenses and growth in sponges would be expected.

A growth-defense trade-off in sponges is supported by some indirect evidence. Hoppe (1988a) found variability between predation deterrence, growth and healing in 3 defended sponges, Neofibularia nolitangere, Ircinia strobilina and Agelas clathrodes, and concluded that the variability may be due to differences in resource allocation strategies. Walters \& Pawlik (2005) investigated wound healing in 10 species of Caribbean coral reef sponges, and found that undefended species had faster rates of wound healing than defended species. Wound healing occurs after sponge tissues are damaged, and proceeds at a much faster rate than regular somatic growth (Ayling 1983). In sponge species that were grazed often by sponge-eating fishes, rapid wound healing occurred to repair damaged tissue and prevented microbial colonization and necrosis (Ayling 1983, Walters \& Pawlik 2005).

More recently, Pawlik et al. (2008) examined patterns of colonization on a large shipwreck off Key Largo, Florida, USA, 4 yr after it was sunk to form an artificial reef. Chemically undefended sponge species predominated on the surface of the wreck in terms of both size and abundance compared to the sponge community on surrounding reefs. Small individual recruits of several common defended sponge species were only found in a subsequent survey 18 mo later. Pawlik et al. (2008) concluded that undefended sponge species exhibited some combination of greater reproduction (faster recruitment) or more rapid growth, consistent with a trade-off between chemical defense and growth or reproduction.
As a more direct investigation of trade-offs between growth and chemical defense in co-occurring undefended and defended sponge species, we conducted a series of $\sim 6$ mo predator exclusion experiments over 9 yr using 7 species of branching sponges that commonly occur on Caribbean coral reefs. Although experiments with a larger number of sponge species of differing morphologies might seem ideal, we discovered in preliminary experiments that interspecific comparisons of growth were only valid among morphologically similar species. For example, mound-forming or lobate species sustained greater damage when cut for transplantation, which reduced their survival and likely affected or delayed the rate of subsequent growth. Branching species sustained less tissue damage during collection, were easier to transplant and secure, and had higher survival rates after transplantation than species with other morphologies. For the present study, we chose the undefended species Callyspongia armigera, Iotrochota birotulata and Niphates erecta, and the defended species Amphimedon compressa, Aplysina cauliformis, Aplysina fulva and Ptilocaulis walpersi because they are the most abundant branching sponges on Caribbean reefs (Engel \& Pawlik 2005). We predicted that undefended species would grow faster in the absence of predation, consistent with the hypothesis that sponge species have evolved different allocation patterns to deal with resource constraints.

\section{MATERIALS AND METHODS}

Predator exclusion experiments were conducted on North Dry Rocks reef $\left(25^{\circ} 07.850^{\prime} \mathrm{N}, 80^{\circ} 17.521^{\prime} \mathrm{W}\right)$ off Key Largo, Florida, at 8 to $10 \mathrm{~m}$ depth. Cube-shaped cages measuring $30 \mathrm{~cm}$ on a side were constructed with plastic vexar mesh having $2.5 \mathrm{~cm}$ square openings held together with cable ties and secured to one end of a $30 \times 60 \mathrm{~cm}$ vexar base that was firmly attached to the limestone substratum with several galvanized steel nails topped by $5 \mathrm{~cm}$ diameter plastic washers. In the center of the bottom of each cage, a single cored, red clay brick, $19 \times 9 \times 5 \mathrm{~cm}$, was fixed to the vexar base with cable ties, and a second brick was similarly attached in the center of the half of the vexar base outside the cage. Therefore, each mesh cage contained a brick and shared a common mesh base with a brick outside the cage. We did not include cage controls in these experiments (a third treatment in which cages have one or more sides left open) because the results of preliminary experiments showed they were unnecessary (no difference in the growth of defended species inside and outside of cages). Moreover, while cages may have some effect of altering flow around suspen- 
sion-feeding sponges that could reduce feeding capability, this effect would be in the opposite direction from the outcome expected for undefended sponge species (caged sponges will not be grazed and should grow more); therefore, enhanced growth of caged versus uncaged sponges would be a conservative result.

Sponges were collected from the surrounding reef at North Dry Rocks. Only sponges that were free of zoanthids or epibionts were used in experiments. Pieces of sponge $\sim 10 \mathrm{~cm}$ in length were carefully cut with a sharp razor and kept immersed in seawater while being transported to the laboratory, where each piece was given a unique numbered tag and weighed to the nearest $0.01 \mathrm{~g}$ using an electronic scale. Sponges were kept submerged as much as possible to avoid air bubble formation in their tissues. Within a few hours, sponges were transported back to the same reef from which they had been collected and each piece was randomly secured on the side of a brick with a cable tie, either inside or outside of a cage. At the end of 4 to 6 mo, sponges were retrieved and transported back to the laboratory, where they were kept submerged, their tags cleaned of any fouling organisms and then weighed as before.

Nine successful iterations of the experiment were conducted between 1999 and 2008, with 1 to 4 sponge species used in each iteration and 20 caged and 20 uncaged sponge pieces per species. Of the 9 iterations, 6 were conducted in the summer and 3 in the winter. Winter runs were added later, starting in 2005. Details are summarized in Table 1.

For each sponge piece, a growth index (GI, \% g ginal ginitial $^{-1} \mathrm{~d}^{-1}$ ) was calculated as follows:

$$
\text { GI }=100 \times\left(m_{\mathrm{f}} / m_{\mathrm{i}}\right) / d
$$

where $m_{\mathrm{f}}$ and $m_{\mathrm{i}}$ are the final and initial masses $(\mathrm{g})$ of the sponges, respectively, and $d$ is the duration of the experiment (d). This index was comparable across experimental iterations that were run for different

Table 1. Details of growth experiments run at North Dry Rocks in Key Largo, Florida. ACA: Aplysina cauliformis; ACO: Amphimedon compressa; AF: Aplysina fulva; CA: Callyspongia armigera; IB: Iotrochota birotulata; NE: Niphates erecta; PW: Ptilocaulis walpersi. Species names in bold are chemically defended

\begin{tabular}{|cccccc|}
\hline Year & Season & Start date & End date & Duration $(\mathrm{d})$ & Species \\
\hline 2007 & Winter & 29 Nov 07 & 07 May 08 & 160 & CA, IB, ACO, ACA \\
2007 & Summer & 04 Jun 07 & 28 Nov 07 & 176 & CA, IB, ACO, ACA \\
2006 & Winter & 15 Nov 06 & 29 May 06 & 195 & CA, IB, ACO, ACA \\
2006 & Summer & 25 May 06 & 12 Nov 06 & 171 & CA, IB, ACO, ACA \\
2005 & Winter & 12 Dec 05 & 23 May 05 & 162 & CA, ACA \\
2003 & Summer & 05 Jun 03 & 06 Oct 03 & 124 & CA, IB, NE, AF \\
2002 & Summer & 07 May 02 & 14 Oct 02 & 159 & CA, NE, AF \\
2000 & Summer & 06 May 00 & 03 Oct 00 & 151 & CA, IB, ACA, PW \\
1999 & Summer & 12 May 99 & 05 Oct 99 & 147 & IB \\
\hline
\end{tabular}
si. Growth rates of sponges in cages ranged from 0 to $133 \%$ growth $\mathrm{yr}^{-1}$, while uncaged sponges had slightly lower growth rates of -1 to $105 \%$ growth $\mathrm{yr}^{-1}$. In cages, where the effects of fish predation were removed, growth rates of undefended sponge species were consistently higher than those of defended species (110.4 versus $65.8 \%$ growth $\mathrm{yr}^{-1}$ ).

There was a significant interaction between treatment and defense (ANOVA, $F=5.53, \mathrm{df}=1,1150, \mathrm{p}=0.0189$; Table 2, Fig. 2). Among the undefended species, caged sponges exhibited significantly greater growth than uncaged sponges (mean $\pm \mathrm{SE}, 0.93 \pm 0.01$ versus $0.86 \pm$ $0.01 \% \mathrm{~g}_{\text {final }} \mathrm{g}_{\text {initial }}{ }^{-1} \mathrm{~d}^{-1} ; t=3.94, \mathrm{df}=1150$, $\mathrm{p}<0.0001$ ), and this difference was corroborated by evidence of bite marks on uncaged, undefended sponges at the end of each experiment. There were no differences in growth between caged and uncaged sponges among the defended species $(0.78 \pm 0.01$ versus $0.77 \pm 0.01 \%$ $\mathrm{g}_{\text {final }} \mathrm{g}_{\text {initial }}{ }^{-1} \mathrm{~d}^{-1} ; t=0.42, \mathrm{df}=1150, \mathrm{p}=$ 0.672 ). For both caged and uncaged sponges, undefended species exhibited greater growth overall than defended species $(0.89 \pm 0.01$ versus $0.77 \pm 0.01 \%$ $\left.g_{\text {final }} g_{\text {initial }}{ }^{-1} \mathrm{~d}^{-1}\right)$.

There was also a significant interaction between season and defense 


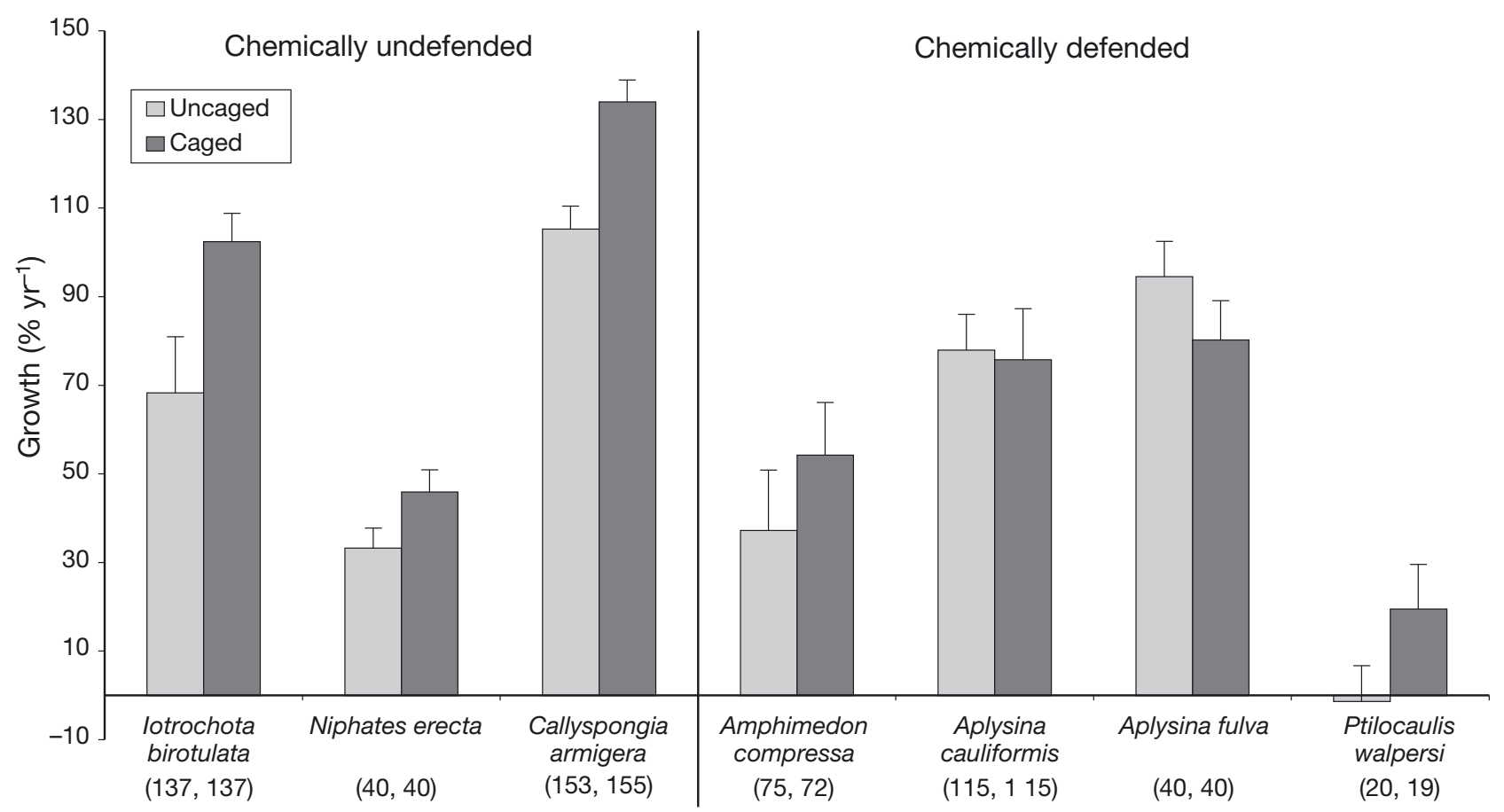

Fig. 1. Yearly growth rates (mean + SE) of Caribbean coral reef sponges in uncaged and caged treatments on reefs off Key Largo, Florida. Number of replicates (uncaged, caged) are shown below each species name

Table 2. ANOVA results on differences in growth rate of Caribbean coral reef sponges. Significant factors are marked by an asterisk

\begin{tabular}{|lcrc|}
\hline Source & $\mathrm{df}$ & \multicolumn{1}{c|}{$F$} & $\mathrm{p}$ \\
\hline Season (winter/summer) & 1,1150 & 40.42 & $<0.0001^{*}$ \\
Defense (defended/undefended) & 1,1150 & 76.33 & $<0.0001^{*}$ \\
Treatment (caged/uncaged) & 1,1150 & 8.86 & $0.0030^{*}$ \\
Season $\times$ Defense & 1,1150 & 10.01 & $0.0016^{*}$ \\
Season $\times$ Treatment & 1,1150 & 1.05 & 0.3051 \\
Defense $\times$ Treatment & 1,1150 & 5.53 & $0.0189^{*}$ \\
Season $\times$ Defense $\times$ Treatment & 1,1150 & 0.00 & 0.9997 \\
\hline
\end{tabular}

(ANOVA, $F=10.01$, df $=1,1150, \mathrm{p}=0.002 ;$ Table 2, Fig. 3). Growth occurred in both summer and winter, but winter growth rates were lower than summer growth rates for both undefended and defended sponge species. The defended and undefended species differed in the extent to which growth was reduced in winter. Among the undefended species, winter growth was lower than summer growth $(0.87 \pm$ 0.02 versus $0.92 \pm 0.01 \% g_{\text {final }} g_{\text {initial }}{ }^{-1} \mathrm{~d}^{-1} ; t=2.36, \mathrm{df}=$ $1150, p=0.018)$, but for defended species, the difference between winter and summer growth was greater $\left(0.71 \pm 0.02\right.$ versus $0.84 \pm 0.01 \% \mathrm{~g}_{\text {final }}$ ginitial $^{-1} \mathrm{~d}^{-1} ; t=$ 6.46 , df $=1150, \mathrm{p}<0.0001)$.

When the same statistical analyses as shown above on growth index data (Fig. 2) were performed on un-

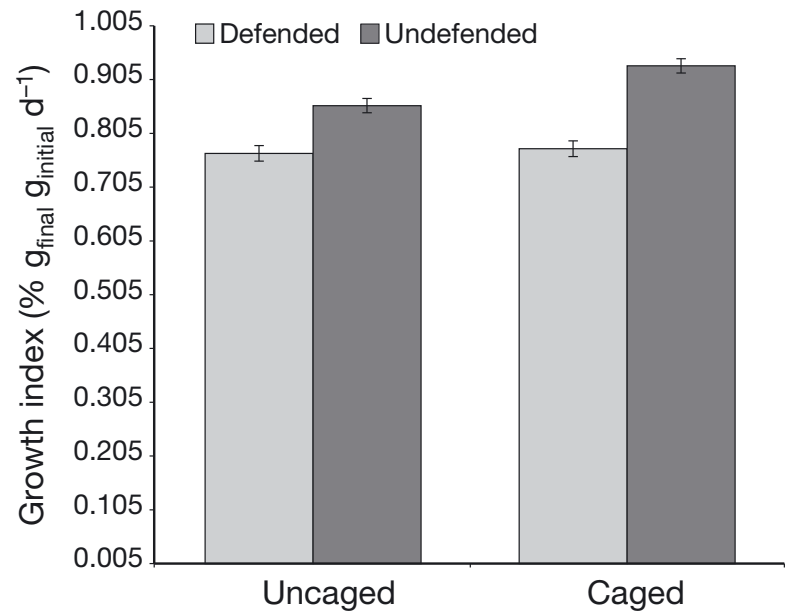

Fig. 2. Daily growth (mean $\pm \mathrm{SE}$ ) using the growth index in uncaged and caged treatments for undefended (Callyspongia armigera, Iotrochota birotulata and Niphates erecta) and defended sponge species (Amphimedon compressa, Aplysina cauliformis, Aplysina fulva and Ptilocaulis walpersi) on reefs off Key Largo, Florida. $\mathrm{N}=1158$

transformed yearly percentage growth data, the same main factors and interaction terms were significant with the exception of season. The reason for this was that summer experimental runs were shorter than winter runs, and transformation of the yearly percentage growth data to produce growth index data removed this bias. 


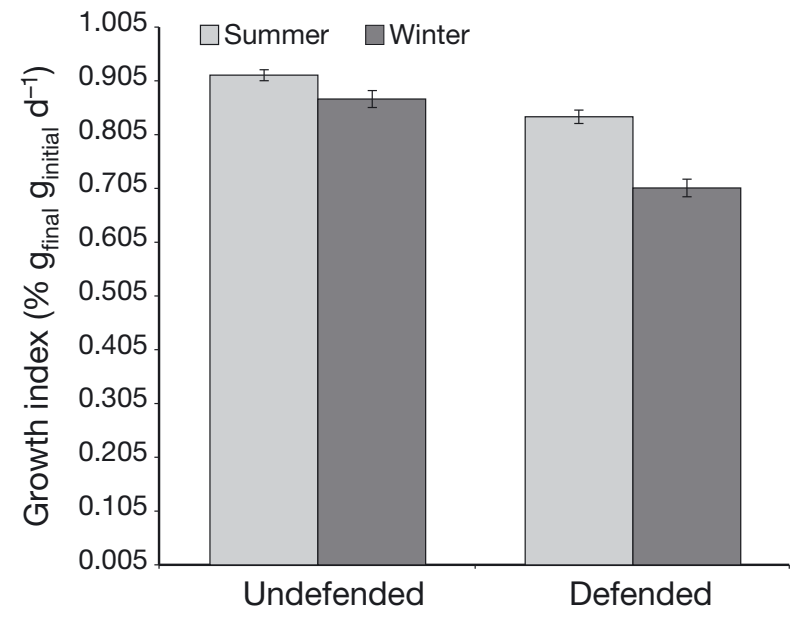

Fig. 3. Daily growth (mean $\pm \mathrm{SE}$ ) using the growth index for undefended (Callyspongia armigera, Iotrochota birotulata and Niphates erecta) and defended sponge species (Amphimedon compressa, Aplysina cauliformis, Aplysina fulva and Ptilocaulis walpersi) in different seasons (summer/winter) on reefs off Key Largo, Florida. $\mathrm{N}=1158$

\section{DISCUSSION}

\section{Growth and chemical defense}

From the foregoing comparison of growth among 7 of the most common branching sponge species on Caribbean reefs, there is clear evidence for a trade-off between growth and chemical defenses. Growth was greater in undefended sponge species that tolerate rather than resist predation by sponge-eating fishes. This, combined with evidence of faster healing rates among undefended sponges (Walters \& Pawlik 2005) and faster recruitment or growth rates of undefended sponges (Pawlik et al. 2008), extends the concept of resource allocation trade-offs described for terrestrial plants (Coley et al. 1985, Bazzaz et al. 1987, Bazzaz \& Grace 1997) and marine algae (Dworjanyn et al. 2006) to Caribbean sponges.

The results of the present study compliment those of a previous investigation of Caribbean sponge recruitment onto a shipwreck adjacent to coral reefs off Key Largo, Florida (Pawlik et al. 2008). The shipwreck lies along the same reef track as the experiments conducted in the present study. Chemically undefended sponge species dominated the surface of the shipwreck 4 yr after it was sunk as an artificial reef, with initial recruits of chemically defended species evident 18 mo later. While the shipwreck survey results supported the resource allocation trade-off hypothesis, the importance of growth versus reproduction relative to chemical defense could not be untangled (Pawlik et al. 2008). Iotrochota birotulata, the second most abundant sponge on the shipwreck, was also the second fastest-growing sponge in the present study, suggesting that resources are directed toward faster growth in this undefended species. Two species of vase-shaped Callyspongia were the next 2 most common sponges on the wreck, and $C$. armigera was the fastest-growing sponge in the present study. We have observed that all Callyspongia spp. grow rapidly, but the thinly branching $C$. armigera is not found in high flow environments such as the shipwreck site (W. Leong \& J. R. Pawlik unpubl. data). Interestingly, Desmapsamma anchorata, the most abundant sponge on the shipwreck and a branching species, is not commonly found on adjacent reefs because it is a preferred food of parrotfishes, which were not present on the shipwreck, likely because of the presence of large predatory sharks and groupers (J. R. Pawlik pers. obs.). Niphates erecta had much lower growth rates than the other 2 undefended sponges in the present study, even though it was the fifth most abundant sponge on the shipwreck (Pawlik et al. 2008). Unlike other branching species, $N$. erecta grows against the substratum rather than up into the water column, which may affect its ability to feed and grow. However, the fact that it was among the most abundant sponges on the shipwreck suggest that it may divert resources to a greater relative degree toward reproduction, allowing it to recruit faster to available substrata.

Observations of fish feeding on reef sponges have demonstrated that spongivorous fishes selectively feed on undefended sponges (Dunlap \& Pawlik 1996, Pawlik 1997, Loh \& Pawlik 2009). In the present study, fish predation on uncaged undefended sponges reduced their growth rate compared to sponges in the caged treatments. Chemically defended sponges grew at the same rates in both caged and uncaged treatments. Selective predation on undefended species that coexist with defended species has also been reported for plants and lichens (Coley 1983, Westerbergh \& Nyberg 1995, Nimis \& Skert 2006). This type of predation on undefended species, which allocate more resources to growth, may provide the balance that allows both chemically defended and undefended sponge species to occur on the same reef.

Growth, like wound healing, should be negatively correlated with defense, but continuous investment of resources in growth is different from faster wound healing, which is a response triggered by tissue damage (Ayling 1983). Undefended sponge species are not only able to respond more quickly after predation to regenerate lost tissue (Walters \& Pawlik 2005), but they also invest more in growth that occurs independent of tissue damage. We evaluated the relationship between growth rate and chemical defense in the same manner as Walters \& Pawlik (2005), plotting growth rates of caged sponges against palatability (Fig. 4). The palatability data (Pawlik et al. 1995) are from fish feeding assays of crude organic ex- 


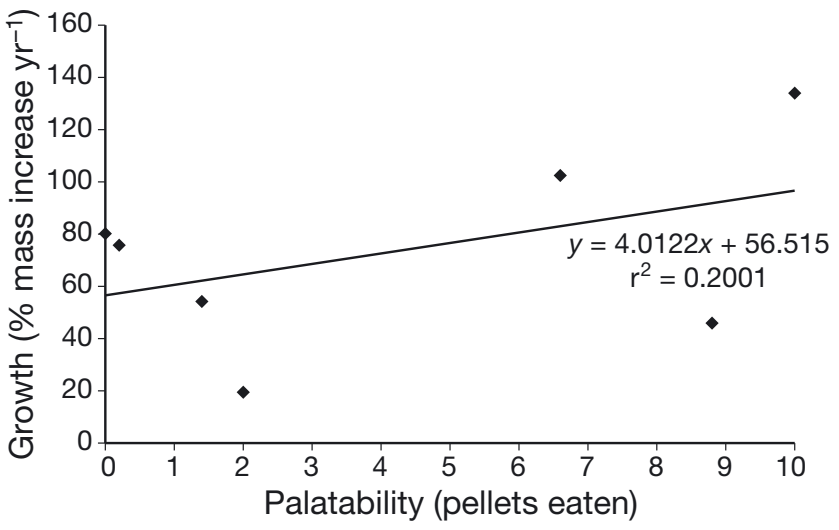

Fig. 4. Relationship between yearly growth (in cages) and chemical defense for 7 species of common branching sponges (Callyspongia armigera, Iotrochota birotulata, Niphates erecta, Amphimedon compressa, Aplysina cauliformis, Aplysina fulva and Ptilocaulis walpersi) from Caribbean coral reefs. Means are shown without variance for clarity. Palatability data are from Pawlik et al. (1995) and a similar figure is presented in Walters \& Pawlik (2005) for the relationship between wound healing and chemical defense

tracts of sponge tissue in artificial food pellets at natural concentrations, scoring the number of extract-treated pellets eaten out of 10 , with 10 being completely palatable and 0 being completely deterrent. Using the same analysis as Walters \& Pawlik (2005), palatability correlated with growth for the branching sponge species used in the present study (Fig. 4), but growth was more poorly correlated with palatability than wound healing $\left(\mathrm{r}^{2}=\right.$ 0.20 versus 0.64 , respectively). Regular growth is not a response to tissue damage, unlike wound healing, and thus would not be expected to correlate as tightly with palatability. Furthermore, during normal growth, resources can be allocated to remodeling the tissue matrix in ways that do not result in an overall increase in mass. More importantly, the situation is more complicated than a trade-off solely between defense and growth: sponges may also be investing more or less in reproduction, and relative differences in investment between growth and reproduction between undefended species may obscure the relationship between growth and defense, as for some terrestrial plants (Mole 1994) and marine algae (Dworjanyn et al. 2006). In this case, the relationship is also obscured by the large range of growth rates within both undefended and defended sponge species. For example, Niphates erecta grew more slowly than the other 2 undefended species (Fig. 1), and may be diverting more energy into reproduction rather than growth. An examination of the trade-off between chemical defense and reproduction among the same sponge species would be useful to obtain a more complete picture of resource allocation.

Direct tests of the cost of chemical defenses are rare, but have been attempted with plants, and are compli- cated by co-varying responses to environmental factors and trade-offs between growth and reproduction (Dworjanyn et al. 2006). Of the sponge species tested for the present study, Callyspongia armigera, Iotrochota birotulata and Niphates erecta lacked chemical defenses (Pawlik et al. 1995), while Amphimedon compressa produces a pyridinium alkaloid that is highly deterrent to predators (Albrizio et al. 1995), Aplysina spp. contain unpalatable brominated tyrosine derivatives (Puyana et al. 2003, Nuñez et al. 2008) and Ptilocaulis walpersi contains deterrent bromopyrroles and oroidin-class metabolites similar to members of the genus Agelas (Wright et al. 1991, Assmann et al. 2000). The biosynthetic pathways for sponge secondary metabolites are poorly understood, but the process is likely to be costly, as may also be the storage of metabolites and the prevention of autotoxicity (Van Alstyne et al. 2001). While it has been suggested that some invertebrates gain the advantages of chemical defenses produced by their microbial symbionts at little or no direct cost to the invertebrate host (Haygood et al. 1999), the trade-offs demonstrated in the present study provide evidence that chemical defenses are costly to Caribbean sponges.

Direct measurement of wet mass before and after the experimental time course proved to be a valuable method for determining sponge growth in the present study, with nearly $100 \%$ survivorship of experimental sponge pieces several days after manipulation. High survivorship was likely tied to the rapid redeployment of sponge pieces at $>6 \mathrm{~m}$ depth, as any air bubbles caught inside the sponge aquiferous system during weighing were compressed and expelled. Determining growth of sponges has been difficult because most species exhibit multi-directional discontinuous growth. Indirect methods of measurement have generally been used because of the perceived inability of sponges to survive manipulation or because of the size of some species. For example, growth rates of massive species have been estimated from before-and-after photographic images, with varying degrees of correction for internal cavities (Reiswig 1973, Dayton et al. 1974, McMurray et al. 2008). The growth of boring or encrusting species has been studied using 2-dimensional images (Hill 1996, Turon et al. 1998, respectively). Growth from larval recruitment to full size has been estimated for sponges on a shipwreck having a known sinking date (Pawlik et al. 2008). For branching species, growth has been estimated by measuring sponges with a tape measure in the field and approximating final sponge volume with the volume of multiple combined geometric solids (e.g. Wulff 2005), a technique we attempted and found to be both imprecise and inaccurate when compared to the one presented herein. For Callyspongia biru, another branching species, new growth could be visually 
distinguished and separated from the original sponge, allowing dry mass determinations of the original piece and new growth at the conclusion of the experiment (de Voogd 2007). While photographic methods are likely necessary for large species, and the estimations that come from them appropriate for demographic purposes (Reiswig 1973, McMurray et al. 2008), the use of before-and-after wet mass determinations are preferable when examining growth differences in short-term manipulative experiments.

\section{Growth rates and seasonality}

Growth occurred for all sponge species except for the uncaged treatment of Ptilocaulis walpersi, a chemically defended species. Negaftive growth, or shrinkage, has been described for other sponge species (Elvin 1976, Hoppe 1988a, Garrabou \& Zabala 2001, McMurray et al. 2008). Growth rates of uncaged sponge species were comparable to rates reported in the literature. For example, the giant barrel sponge Xestospongia muta increased in volume at a rate of $52 \% \mathrm{yr}^{-1}$ (McMurray et al. 2008). Hoppe (1988a) found growth rates of 7 to $19 \% \mathrm{yr}^{-1}$ for Neofibularia nolitangere, Ircinia strobilina and Agelas clathrodes, and Reiswig (1973) reported growth rates of 5 to $60 \% \mathrm{yr}^{-1}$ for Mycale sp., Verongula gigantea and Tethya crypta in Jamaica. Our results reveal that some rope sponges have very high growth rates, with Aplysina fulva and Callyspongia armigera able to double their mass per year.

Sponge growth was higher in summer than in the winter. Seasonal differences in sponge growth have been attributed to both physical factors (temperature, environmental stress, water flow and depth) and physiological factors related to resource allocation tradeoffs (e.g. seasonal reductions in growth due to investment in reproduction). For the most part, physical factors that affect growth are linked to food availability and delivery, with higher growth occurring in the warmer months of higher primary productivity when more food is available (Elvin 1976, Duckworth et al. 2004, McMurray et al. 2008). Barthel (1986) did not find any correlations between temperature and food availability in the Baltic Sea, and suggested that temperature may be linked with respiration rates to explain growth patterns. Depth-associated picoplankton availability has been implicated in the growth in some Caribbean sponge species (Lesser 2006, Trussell et al. 2006) but not others (McMurray et al. 2008). Duckworth et al. (2004) found that sponges grew fastest in areas of high flow and postulated that this may be due to improved delivery of food, which enables sponges to feed with minimal pumping. Verdenal \& Vacelet (1990) reported that increased turbidity decreased growth in sponges, and suggested that this may be due to clogging of sponge pores that obstruct feeding. Seasonal growth may also change because of concomitant changes in reproductive output (Turon et al. 1998) or conversion of feeding choanocytes to sperm cells (Duckworth et al. 2004).

For the sponge species used in the present study, higher growth in the warm summer months (MayOctober) corresponded with higher rates of reproduction (W. Leong unpubl. data). Similar data have been reported for other Caribbean sponge species (Reiswig 1976, Hoppe 1988b). Therefore, changes in growth rates appear to be independent of the timing of reproduction, but both may be tied to the metabolic constraints of temperature or food availability. If resources are more limited in winter, then defended sponge species would be expected to grow less because allocation to defense would consume a greater proportion of the overall resources available, assuming that the cost of metabolite production and storage remains constant throughout the year. The significant interaction between season and defense observed in the data reported herein support this expectation. Therefore, seasonal patterns of sponge growth are also consistent with the resource allocation hypothesis.

In summary, trade-offs between chemical defenses and growth, and in seasonal patterns of growth, support the resource allocation hypothesis for a group of common branching sponges on Caribbean coral reefs. Although a trade-off was found, a low level of correlation between growth and defense may indicate that other resource trade-offs are obscuring the relationship. The interaction between reproductive output and chemical defense among the same group of branching sponge species may help to further explain this relationship.

Acknowledgements. This study was funded by grants to J.R.P. from NOAA's Coral Reef Conservation Program to the National Undersea Research Program at the University of North Carolina Wilmington (NOAA NA96RU-0260) and from the National Science Foundation, Biological Oceanography Program (OCE-0095724, 0550468). Permission to perform experiments was provided by the Florida Keys National Marine Sanctuary. Particular thanks to the staff of NOAA/NURC in Key Largo, Florida, for logistical support, and to J. Blum for statistical advice. Assistance in the field was provided by A. Bright, J. Cowart, S. Engel, N. Foster, J. Gavin, T. Henkel, A. Jones, S. Kelly, S. López-Legentil, T.L. Loh, G. McFall, S. Odate, W. O'Neal, D. Swearingen, K. Walters and K. Whalan.

\section{LITERATURE CITED}

Agrawal AA (2007) Macroevolution of plant defense strategies. Trends Ecol Evol 22:103-109

- Albrizio S, Ciminiello P, Fattorusso E, Magno S, Pawlik JR (1995) Amphitoxin, a new high molecular weight antifeedant pyridinium salt from the Caribbean sponge Amphimedon compressa. J Nat Prod 58:647-652 
Assmann M, Lichte E, Pawlik JR, Köck M (2000) Chemical defenses of the Caribbean sponges Agelas wiedenmayeri and Agelas conifera. Mar Ecol Prog Ser 207:255-262

Ayling A (1983) Growth and regeneration rates in thinly encrusting Demospongiae from temperate waters. Biol Bull 165:343-352

Barthel M (1986) On the ecophysiology of the sponge Halichondria panicea in Kiel Bight. I. Substrate specificity, growth and reproduction. Mar Ecol Prog Ser 32:291-298

Bazzaz FA, Grace J (1997) Plant resource allocation. Academic Press, San Diego, CA

Bazzaz FA, Chiariello NR, Coley PD, Pitelka LF (1987) Allocating resources to reproduction and defense. Bioscience 37:58-67

Berenbaum MR, Zangerl AR (2008) Facing the future of plantinsect interaction research: le retour à la 'raison d'être'. Plant Physiol 146:804-811

Coley PD (1983) Intraspecific variation in herbivory on two tropical tree species. Ecology 64:426-433

> Coley PD, Bryant JP, Chapin FS (1985) Resource availability and plant antiherbivore defense. Science 230:895-899

> Dayton PK, Robilliard GA, Paine RT, Dayton LB (1974) Biological accommodation in the benthic community at McMurdo Sound, Antarctica. Ecol Monogr 44:105-128

$>$ de Voogd NJ (2007) The mariculture potential of the Indonesian reef-dwelling sponge Callyspongia (Euplacella) biru: growth, survival and bioactive compounds. Aquaculture 262:54-64

> Duckworth AR, Battershill CN, Schiel DR (2004) Effects of depth and water flow on growth, survival and bioactivity of two temperate sponges cultured in different seasons. Aquaculture 242:237-250

- Dunlap M, Pawlik JR (1996) Video-monitored predation by Caribbean reef fishes on an array of mangrove and reef sponges. Mar Biol 126:117-123

- Dworjanyn SA, Wright JT, Paul NA, de Nys R, Steinberg PD (2006) Cost of chemical defence in the red alga Delisea pulchra. Oikos 113:13-22

Elvin D (1976) Seasonal growth and reproduction of an intertidal sponge, Haliclona permollis (Bowerbank). Biol Bull 151:108-125

Engel S, Pawlik JR (2005) Interactions among Florida sponges. I. Reef habitats. Mar Ecol Prog Ser 303:133-144

Fine PVA, Miller ZJ, Mesones I, Irazuzta S and others (2006) The growth-defense trade-off and habitat specialization by plants in Amazonian forests. Ecology 87:150-162

Garrabou J, Zabala M (2001) Growth dynamics in four Mediterranean demosponges. Estuar Coast Shelf Sci 52:293-303

Haygood MG, Schmidt EW, Davidson SK, Faulkner DJ (1999) Microbial symbionts of marine invertebrates: opportunities for microbial biotechnology. J Mol Microbiol Biotechnol 1: 33-43

Herms DA, Mattson WJ (1992) The dilemma of plants: to grow or defend. Q Rev Biol 67:283-335

Hill MS (1996) Symbiotic zooxanthellae enhance boring and growth rates for the tropical sponge Anthosigmella varians forma varians. Mar Biol 125:649-654

Hoppe WF (1988a) Growth, regeneration and predation in three species of large coral reef sponges. Mar Ecol Prog Ser 50:117-125

- Hoppe WF (1988b) Reproductive patterns in three species of large coral reef sponges. Coral Reefs 7:45-50

> León YM, Bjorndal KA (2002) Selective feeding in the hawksbill turtle, an important predator in coral reef ecosystems. Mar Ecol Prog Ser 245:249-258

Lesser MP (2006) Benthic-pelagic coupling on coral reefs: feeding and growth of Caribbean sponges. J Exp Mar Biol Ecol 328:277-288

Editorial responsibility: James McClintock, Birmingham, Alabama, USA
Loh TL, Pawlik JR (2009) Bitten down to size: fish predation determines growth form of the Caribbean coral reef sponge Mycale laevis. J Exp Mar Biol Ecol 374:45-50

McMurray SE, Blum JE, Pawlik JR (2008) Redwood of the reef: growth and age of the giant barrel sponge Xestospongia muta in the Florida Keys. Mar Biol 155:159-171

Mole S (1994) Trade-offs and constraints in plant-herbivore defense theory: a life-history perspective. Oikos 71:3-12

> Nimis P, Skert N (2006) Lichen chemistry and selective grazing by the coleopteran Lasioderma serricorne. Environ Exp Bot 55:175-182

Nuñez CV, de Almeida EVR, Granato AC, Marques SO and others (2008) Chemical variability within the marine sponge Aplysina fulva. Biochem Syst Ecol 36:283-296

Pawlik JR (1997) Fish predation on Caribbean reef sponges: an emerging perspective of chemical defenses. Proc 8th Int Coral Reef Symp 2:1255-1258

Pawlik JR (1998) Coral reef sponges: Do predatory fishes affect their distribution? Limnol Oceanogr 43:1396-1399

Pawlik JR, Chanas B, Toonen RJ, Fenical W (1995) Defenses of Caribbean sponges against predatory reef fish. I. Chemical deterrency. Mar Ecol Prog Ser 127:183-194

Pawlik JR, Henkel TP, McMurray SE, López-Legentil S, Loh TL, Rohde S (2008) Patterns of sponge recruitment and growth on a shipwreck corroborate chemical defense resource trade-off. Mar Ecol Prog Ser 368:137-143

Puyana M, Fenical W, Pawlik JR (2003) Are there activated chemical defenses in sponges of the genus Aplysina from the Caribbean? Mar Ecol Prog Ser 246:127-135

Randall JE, Hartman WD (1968) Sponge-feeding fishes of the West Indies. Mar Biol 1:216-225

Reiswig HM (1973) Population dynamics of three Jamaican Demospongiae. Bull Mar Sci 23:191-226

Reiswig HM (1976) Natural gamete release and oviparity in Caribbean Demospongiae. In: Harrison HW, Cowden RR (eds) Aspects of sponge biology. Academic Press, New York, NY, p 99-112

Stamp N (2003) Out of the quagmire of plant defense hypotheses. Q Rev Biol 78:23-55

Trussell GC, Lesser MP, Patterson MR, Genovese SJ (2006) Depth-specific differences in growth of the reef sponge Callyspongia vaginalis: role of bottom-up effects. Mar Ecol Prog Ser 323:149-158

Turon X, Tarjuelo I, Uriz MJ (1998) Growth dynamics and mortality of the encrusting sponge Crambe crambe (Poecilosclerida) in contrasting habitats: correlation with population structure and investment in defence. Funct Ecol 12: 631-639

Van Alstyne KL, Wolfe GV, Freidenburg TL, Neill A, Hicken C (2001) Activated defense systems in marine macroalgae: evidence for an ecological role for DMSP cleavage. Mar Ecol Prog Ser 213:53-65

Verdenal B, Vacelet J (1990) Sponge culture on vertical ropes in the Northwestern Mediterranean Sea. In: Rutzler K (eds) New perspectives in sponge biology. Smithsonian Institution Press, Washington, DC, p 416-424

- Walters KD, Pawlik JR (2005) Is there a trade-off between wound-healing and chemical defenses among Caribbean reef sponges? Integr Comp Biol 45:352-358

- Westerbergh A, Nyberg AB (1995) Selective grazing of hairless Silene dioica plants by land gastropods. Oikos 73:289-298

> Wright AE, Chiles SA, Cross SS (1991) 3-Amino-1-(2Aminoimidazolyl)-prop-1-ene from the marine sponges Teichaxinella morchella and Ptilocaulis walpersi. J Nat Prod 54:1684-1686

Wulff JL (2005) Trade-offs in resistance to competitors and predators, and their effects on the diversity of tropical marine sponges. J Anim Ecol 74:313-321

Submitted: October 9, 2009; Accepted: February 11, 2010

Proofs received from author(s): April 23, 2010 